\title{
CHRISTIANITY AND HOMOSEXUALITY: CONTRADICTORY OR COMPLEMENTARY? A QUALITATIVE STUDY OF THE EXPERIENCES OF CHRISTIAN HOMOSEXUAL UNIVERSITY STUDENTS
}

\author{
S. Nkosi \\ Social Work Department \\ University of the Witwatersrand \\ Johannesburg, South Africa \\ e-mail: nkosisne47@gmail.com
}

\section{F. Masson}

Social Work Department

University of the Witwatersrand

Johannesburg, South Africa

e-mail: Francine.mason@wits.ac.za

\section{ABSTRACT}

Students at tertiary institutions encounter many challenges beyond academic performance, for some these challenges entail the acceptance of their sexual identity alongside their religious beliefs. For centuries, the acceptance of homosexuality within the Christian religion has been a contentious issue. Whilst some Christians believe that Christianity and homosexuality can coexist, others advocate that the notion is contradictory to the basic tenets of the Christian faith. Homosexuals and bisexuals are generally considered marginalised groups in society, which have experienced discrimination in many ways. Drawing on social identity theory and utilising a qualitative approach this phenomenological research study aimed to explore the individual experiences, views and opinions of ten students about their sexuality and their religion. All participants acknowledged that they were either homosexual or bisexual and considered themselves to be Bible-believing Christians. Snowball sampling was used to identify and invite potential participants to be part of the research study. The researcher used a semi-structured interview schedule to guide the interviews which were recorded with the participants' consent. Data were analysed using thematic content analysis. The main findings of the research indicated that participants experienced the church as a very unwelcoming environment and fellow Christians as extremely judgemental. Feelings of rejection and of isolation were reinforced by people and a system that participants felt should have been supportive. This study holds potential benefits for educators and counselling practitioners at university institutions as it provides the opportunity to learn about the dynamics and views of this often marginalised group whose religious experiences may adversely impact on their studies.

Keywords: homosexuality, bisexuality, Christianity, coming out, students, discrimination 


\section{INTRODUCTION}

Students studying at universities have many challenges to face, not only on an academic level but also in their own quest for identity and purpose in life. According to Sakin Ozen, Ercan, Irgil and Sigirli, $(2010,127)$ university youth may experience numerous psychological issues as they are often sensitive to intrapersonal, interpersonal and sociocultural differences and conflicts specially as students are generally at a stage in their lives when they are open to change. Social identity theory is the framework for this study and advocates that a person' $s$ sense of identity and self-esteem is largely influenced by their group memberships (Tajfel and Turner 1979, 33). As individuals strive to reach a positive social identity, they compare themselves to groups with which they can identify as well as groups with which they don't (Niens, Cairns, Finchilescu, Foster and Tredoux 2003, 109). For Christian students who are not heteronormative, the journey of self-acceptance and of acceptance - or lack of acceptance from others within their faith may be a complicated process. This often tumultuous journey can have numerous adverse effects on students' academic performance and requires further investigation in order to create understanding and awareness of the challenges that these students may face.

Traditionally, the religion of Christianity promotes heterosexuality and does not advocate for acceptance of homosexuality or bisexuality. The debate whether homosexuality is a sinful act in the eyes of the Lord has been continuing on for centuries - a debate that does not appear to be drawing to any definitive conclusion in the near future. The pairing of these two aspects has often led to conflict for homosexuals who practise Christianity (Rodriguez and Ouellette 2000, 333). While some may view the combining of these two aspects to be contradictory, many believe that homosexual Christians should neither abandon their Christian beliefs nor their sexual orientation. The decision taken by these Christians, to continue practising both homosexuality and Christianity, has been accompanied by varied responses from the church and other Christians. These responses vary from hostile to sympathetic, discriminating to accepting, rejecting to welcoming. Amidst the negativity there are positive responses as well. However, it needs to be noted that negative responses from the church and other Christians are still very prevalent in South Africa, which has often adversely affected the Christians who do not subscribe to being heterosexual.

As this debate continues, homosexual Christians continue to try to figure out a balance or a way of merging these two very important aspects of their lives. Merging or finding a balance may be a very difficult and complicated process. This research aimed to explore the experiences of university students who are Christians and homosexual in their quest of merging and 
integrating their religion and sexual orientation. The work of Erikson highlights the importance of identity formation and how identity development and integration continues over time and settings. Specifically, for the homosexual individual, disclosing one's identity to others, working through the prejudiced attitudes of others, and participating in Lesbian, Gay, Bisexual and Transgender (LGBT) related social activities, are essential aspects of identity integration for a homosexual (Rosario, Schrimshaw and Hunter 2011, 5). As university students are often in the later adolescent stage of the life cycle (18-24 years), challenges with identity and intimacy are developmentally appropriate (Newman and Newman 1999, 348). Furthermore, tensions between religious beliefs and sexual orientation could potentially impact on their studies and their ability to fulfil their academic potential, as well as their sense of wellbeing.

This study sought to understand the views and opinions that homosexual Christians have crystallised through their experiences about the church, their sense of self, heterosexual Christians, the Bible, and Christianity as a religion. As both sexuality and religion are rather sensitive topics, people often avoid talking about these issues. It was hoped that through more fervent discussion about these issues there would be more room for differences to be tolerated and even accepted. Many universities have in recent years introduced programmes specifically to assist LGBT students. It was also envisaged that the research would provide social workers and psychologists, particularly those employed at university counselling centres, with more insight into the experiences of homosexual Christians thus enabling them to better understand individuals whose sexual orientation is often criticised by people, especially other Christians.

\section{LITERATURE REVIEW}

\section{Social identity theory}

Social identity theory proposes that people need to know which groups they belong to (ingroups) and which groups they don't belong to (out-groups) in order to understand more about themselves. In evaluating others and one's own sense of social identity, three mental processes occur: namely, social categorisation, social identification and social comparison (McLeod 2008, 3). During the first stage of social categorisation individuals categorise people or aspects so that we understand how they fit and belong in their social environments. Individuals then define which categories they belong to through a process of social identification as they adopt the identities of these groups. During this stage self-esteem is increased and behaviour normative to the group is adopted. In the final stage of social comparison individuals start to compare the groups that they have identified with to other groups. The groups that individuals 
have identified with need to compare favourably with other groups if their self-esteem and positive social identity is to be maintained (McLeod 2008, 2; Tajfel and Turner 1979, 36). For students who are homosexual or bisexual and who identify with the Christian faith, this process of determining their social identity can be complicated as many sectors within the Christian community may only support heteronormative behaviour. Furthermore many cultures, particularly African cultures, do not condone homosexuality and/or bisexuality. As all the participants in the study were African, it was important to understand African cultural views on homosexuality and bisexuality. These religious and cultural perspectives may challenge the individual's sense of social identification and are discussed in the following sections.

\section{Biblical perspectives about homosexuality}

Many theologians argue that throughout the old and the New Testament the practice of homosexuality is condemned. Possibly, the most well-known Old Testament passages that address homosexuality are the scriptures in Leviticus and the biblical account of Sodom and Gomorrah. According to the New King James Version of the Bible, Leviticus 18:22 states that, 'You must not have sexual intercourse with a man as you would with a woman; it is a detestable practice'. Further on this idea is reinforced in Leviticus 20:13, 'If a man lies with a male as he lies with a woman, both of them have committed an abomination. They shall surely be put to death.' Well-known biblical historian, Henry (1811) maintained that according to some Bible analysts it is understood that God destroyed Sodom and Gomorrah for its citizens’ immoral and detestable behaviour that had become an accepted way of life in these two cities.

We see in the book of Genesis chapter 19 verse 5 when the men of Sodom wanted to rape or sodomise the two male visitors who had entered the city of Sodom, it reads 'They called to Lot: Where are the men that came to you tonight? Bring them out to us so that we can have sex with them.' Some authors, such as Gnuse (2015, 72), argue that what was abhorrent to God was not the homosexual act itself but that the people of Sodom were violating the customs of hospitability, which were highly valued in that time in the Middle East. Furthermore, the people of Sodom wanted to use sexual violence to show power and dominance over strangers, displaying a lack of social justice and thereby incurring the wrath of God.

Many scriptures in the New Testament also speak against homosexuality. 1 Cor. 6:9-10 (English Standard Version) reads,

${ }^{9}$ or do you not know that the unrighteous will not inherit the kingdom of God? Do not be deceived: neither the sexually immoral, nor idolaters, nor adulterers, nor men who practice homosexuality, ${ }^{10}$ nor thieves, nor the greedy, nor drunkards, nor revilers, nor swindlers will inherit the kingdom of God. 
This condemnation of homosexuality is also stipulated in 1Tim. 1:10 where the Apostle Paul talks about the unnaturalness of homosexual practice, 'the sexually immoral, men who practice homosexuality, enslavers, liars, perjurers, and whatever else is contrary to sound doctrine'. Again in the book of Romans, the apostle Paul talks about God's wrath against sinful humanity. Chapter 1 vs 26 and 27 reads:

Because of this, God gave them over to shameful lusts. Even their women exchanged natural sexual relations for unnatural ones. 27 In the same way the men also abandoned natural relations with women and were inflamed with lust for one another. Men committed shameful acts with other men, and received in themselves the due penalty for their error.

Many Christians emphatically quote these scriptures and use them as a basis to condemn homosexuality, saying that the Bible is very clear on the position.

Gnuse $(2015,71)$ argues that the word 'homosexuality' in these passages has been incorrectly interpreted from the meaning of the Greek word and that instead the words refer to male prostitutes. Henry (1811) believed that the main purpose of these texts is to understand how humankind has wandered from God. The Apostle Paul explains in his letter to the Romans how it is the nature of humankind to prefer the dark and to do evil, than the light and to do good deeds. He explains that people who have strayed from God hold on to the truth of unrighteousness and reason with themselves to justify their sinful acts. The Apostle Paul then says that God gave humankind over to its shameful lusts because there is no greater slavery than to be given up to your own sinful nature. The book of Romans is thus a call to selfexamination, the end of which should be, a deep conviction of sin, and of the necessity of deliverance from a state of condemnation.

\section{Different Christian perspectives concerning homosexuality}

The Christian church comprises numerous denominations, each with various interpretations of the Bible and Christianity. Within the Christian church, there are numerous positions on the debate of homosexuality and Christianity (Bosman 2009, 2). These contrasting viewpoints are based on different interpretations of the Bible. Traditionalists, who are against homosexuality, argue that sex was strictly intended for procreation purposes. Although not all traditional Christians stand united in this argument, as some argue that it is not a sin to enjoy sex. They argue that is not a sin before God's eyes when a married couple engages in sexual activity not only for procreation purposes but also for pleasure. Only the Roman Catholic Church still holds the teaching that God intended sex for procreation purposes only; they teach that sex is sinful whenever it is not engaged in with the intention of procreating (Crooks and Baur 2013; Ellens 
2006, 8).

A more liberal view about the purpose of sex is that sex is both for pleasure and procreation. The Songs of Solomon describe a married man and a woman enjoying moments of sexual intimacy. In this description, there is no mention of procreation (Crooks and Baur 2013, 179). Further, in Genesis 2:24 it is suggested that sex is for creating oneness and agreement in marriage. The passage reads, 'For this reason a man shall leave his father and his mother, and be joined to his wife; and they shall become one flesh'. The act of intimacy with one's spouse also protects one from sexual temptation which could lead to adultery and fornication. Being intimate can comfort a hurting spouse (Driscoll and Driscoll 2012, 211). These claims are supported by scriptures in the Bible such as 2 Samuel 2:24 which reads as follows: 'Then David comforted his wife, Bathsheba, and went in to her and lay with her, and she bore a son, and he called his name Solomon. And the Lord loved him.'

Yarhouse $(2010,17)$ argues that if sex is not only for procreation purposes and is also for pleasure then why should homosexuals be deprived of sex? Would God condemn a loving, monogamous, relationship? Some Christians acknowledge that individuals may be homosexual but advocate that these individuals must remain celibate as it is the homosexual sexual act that is sinful. Others argue that Jesus came to preach the message of love and acceptance and that God is not an unfair God and would never punish a loving, monogamous, Christ-centred, homosexual relationship.

The second argument against homosexuality is that there are no examples of homosexual marriages in the Bible as homosexuality is unnatural and inconsistent with what God had intended for humans. These Christians argue that there are no examples of gay marriages because in God's eyes all marriages are heterosexual and anything other than that is illegitimate and not recognised. However, liberal Christians justify the lack of homosexual examples in the Bible with a cultural explanation. Gnuse $(2015,70)$ believes the Scriptures are historically and culturally limited. As times change culture also changes. He purports that relying on scriptures which were written thousands of years ago can be limiting as they are not relevant to the culture of today. To further this discourse, Phillips $(2005,17)$, raises the issue of polygamy and how in the olden times that practice was acceptable but now in the New Testament it is not approved of. Exodus 21:10-11 reads, " ${ }^{10}$ If he marries another woman, he must not deprive the first one of her food, clothing and marital rights. ${ }^{11}$ If he does not provide her with these three things, she is to go free, without any payment of money.' McNeill (1993) argues that there are many other examples of behaviours which are regarded as sins but are not mentioned in the Bible because they weren't as prominent when the Bible was written; such as watching pornography, genetic 
manipulation, and drug abuse to name a few.

Another argument presented by Christians who are against homosexuality and believe that same sex relationships are sinful and not acceptable, is simply because God says so in the Bible. Some denominations, such as charismatic and Pentecostal churches, place strong emphasis on the literal interpretation of the bible (Bosman 2009, 4). They maintain that they can all try to explain and interpret but at the end of the day God has given His word and He has said all human beings should live by it. Even if we do not fully understand or cannot explain the rationale behind it, in the end we are expected to obey this precept. They urge that the Bible's teachings should not be ignored as it is the primary source of authority in questions of morality and of faith for all Christians (Yarhouse 2010, 17).

Other liberal Christian groups argue that the rejection of homosexuality is not representative of God's love. They argue that in the New Testament Jesus speaks the gospel of love and acceptance. They believe that homosexuality cannot be separated from other sins and that needs to be understood within the context of the theology of sin (Masango 2002, 956).

Boswell (1979) believes that the hostility and rejection of homosexual behaviour didn't arise from the doctrine of Christianity. According to Boswell (1979) there is no Latin word for homosexuality and that meaning of words could be lost through interpretation as the bible was originally translated from Greek and Hebrew (Mirke-Sellassie 2000, 306). The modern translation of the Bible which is against homosexual behaviour could have been misinterpreted or lost during translation from the original meaning. For instance, he uses Genesis chapter 19 (which has already been quoted above) to show how Bible scriptures can be interpreted and understood in different ways. He explains that many scholars have come to understand that the sin of Sodom was inhospitality and that the story of Sodom was probably not intended as any sort of comment on homosexuality.

\section{African views on homosexuality}

While most European Union countries appear to accept homosexuality (Gerhards 2010, 5), the same views are not held by most African countries. According to Kutsch $(2013,1)$ homosexuality is still considered a crime in 38 African countries and many of these countries still retain their laws against homosexuality that were promulgated during the colonial era. The reason behind this rejection and hostility towards homosexuality that is often provided, is that many African leaders feel that gay rights are against their cultural and religious value systems and consider the advent of homosexuality to be an imposition by Western nations. Homosexuality has been described as a lifestyle which is foreign to Africans and is considered 
morally, culturally and religiously wrong by the majority of the African society (Epprecht, 2013). In some parts of the continent such as Nigeria, Uganda, Tanzania and Sudan, homosexuality is punishable by death. The recent Uganda Anti-Homosexuality Act 2014 also referred to as the 'Kill the Gays' Bill is evidence of the intolerance of homosexuality. Leaders such as Robert Mugabe, the president of Zimbabwe and chairperson of the Southern African Development Community (SADC), have recently expressed the extent to which they are against homosexuality. Mugabe believes that homosexuality is 'un-African', is a 'white disease' and also a 'colonial import'. He has threatened to expel gay-rights promoting diplomats in Zimbabwe, and has stated, 'Europeans must keep their inhuman homosexual practices within their own territories and not try to impose them on Africans'. He often refers to homosexuals as 'worse than pigs and dogs' (New Zimbabwe 2014). However, Kaoma $(2014,230)$ argues that homosexuality existed in Africa long before colonialism and that the criminalisation of homosexuality began in England under Henry VIII and was subsequently spread to all the British colonies. Lopang $(2014,83)$ believes that the need to present homosexuality as foreign to the African continent and to promote heterosexuality as part of the African identity was a 'desperate attempt to define morality through sexual practices'.

\section{The acceptance of homosexuality in South Africa}

While South Africa has one of the most advanced constitutions in the world, it does not necessarily mean that South African society is free of discrimination towards homosexuals. The Lesbian, Gay, Bisexual and Transgendered (LGBT) community continues to confront challenges because of their sexual orientation. Challenges which are faced by these individuals include social stigma, homophobic violence (particularly corrective rape), and high rates of HIV/AIDS infection. In recent years there has also been an increase in reported hate crimes towards homosexuals. In contrast, homosexuality appears to be more acceptable in the modern or developed parts of South Africa, as exemplified by Annual Gay Pride events which are held along the streets of Johannesburg and Cape Town.

In recent years academic institutions have been far more vocal about advocating for LGBT equality. The University of the Witwatersrand publicly declared its opposing stance on the recent anti-homosexual legislation in Nigeria and Uganda which criminalises women and men involved in relationships other than those defined as heterosexual. The university also denounced the targeted violence that has accompanied this legislation in these and other countries (University of the Witwatersrand 2014). In addition, the university has launched the Wits Safe Zones programme in the weeks leading up to the Wits Pride Event. The programme 
aimed to support members of the Lesbian, Gay, Bisexual, Transgendered, Queer, Intersex, Asexual (LGBTQIA) community at Wits University and ensure a campus atmosphere that was supportive, informative and welcoming to all members of the community. The goals of the Safe Zones programme included '1) to increase the overall campus community's understanding and awareness of LGBTQIA issues; 2) to provide a greater sense of safety for the gay, lesbian, bisexual, and transgender student community; 3) to offer information to straight allies in positions where they may be in contact with LGBTQIA people (as classmates, roommates, friends, residents, students, staff, faculty, etc.; 4) to act as a resource of information regarding homophobia, heterosexism, transphobia and LGBTQIA issues at Wits' (University of the Witwatersrand 2014).

The LGBT community has emphatically stated that one's sexual orientation is not a choice that one is free to make; it is beyond people's control to choose their attractions. Therefore members of the LGBT community experience their sexual orientation as part of God's creation and not as a result of an intrinsic orientation to evil (Haslan and Levy 2006). Perceiving the churches' teachings as wrong, not from God, and as sadistic, is perceived as a far more comfortable alternative.

\section{Reconciling Christianity and homosexuality}

Subhi et al. (2011, 13) conducted a study exploring the challenges faced by Christians who are homosexual in their attempt at reconciling their sexual orientation with their religious and spiritual beliefs. Their results showed that the church proposed that the best way to deal with homosexuality is for the individual to deny and overcome their homosexual feelings. Many of the participants in the study adopted this approach, which resulted in deleterious effects to their mental health, as they experienced depression, guilt, anxiety, suicidal ideation, and alienation. In another study, Rosario, Scrimshaw and Hunter (2011, 3) examined the link between acceptance, disclosure of sexual orientation and 'positive affectivity' (They define positive affectivity as a state of mood that embraces happiness and satisfaction). The findings of the study showed that the more open an individual was about sexual orientation the higher their self-esteem and positive affectivity.

The most common source of conflict for Christians who were trying to accept their sexual identity is often religious teachings about homosexuality. This conflict was the main finding of Schuck and Liddle's (2001, 63) study which explored the religious conflicts experienced by homosexual individuals. Their participants all said that their priesthood or religious denomination taught that sex between members of the same gender was a sin or that 
homosexual people were immoral. Another frequently mentioned source of conflict was that the church condemned non-marital sex, which dictates eternal celibacy for homosexuals as most countries do not accept homosexual marriages. Participants felt that there was no place for homosexuals in the faith in which they were raised due to the prejudicial and discriminatory views that emanated from the church. Waidzunas $(2015,171)$ explains that often Christian gays live painful lives in the 'toxic closet', as a result of the fear of condemnation.

\section{Conflicts of religion and sexuality, and the effects on homosexual individuals}

The cognitive and emotional effects experienced by homosexuals that could arise from the conflict between religion and homosexuality were explored in a study by Subhi et al. (2011, 19). In the study it emerged that only a few homosexual Christians were left unaffected by the conflicts they faced because of their contravening sexuality and religion. The fear that they would go to hell or that God had rejected them was the most prominent concern. Feelings of guilt and shame were common as participants felt judged by their religious communities and were made to feel less than human. Participants often felt depressed, had feelings of selfloathing or were suicidal.

Coming to terms with their sexuality is not always an easy process due to the religious conflict. Schuck and Liddle (2001, 63) found that homosexuals identified their homosexual friends as most helpful in dealing with the conflict of being homosexual and Christian. Talking to family members, romantic partners or seeking professional help also assisted. Reading books that addressed the topic of homosexuality and religion also enabled them to gain perspective. Some respondents stated that joining religious homosexual congregations was helpful as they did not feel judged and condemned by members of these congregations.

Rodriguez and Ouellette (2000) identified common strategies adopted by homosexuals when working through these religious conflicts. These included, firstly, rejecting the religious identity of a Christian and becoming atheist or joining a religion that accepts homosexuality; secondly, rejecting the homosexual identity and striving to be heterosexual; and thirdly, developing the skill of 'compartmentalisation', when a compromise between two contravening identities is reached. By keeping the two contravening aspects rigidly separate, conflict resolution is achieved. They are kept separate to avoid conflicting prescriptions for behaviour. A final strategy included, identity integration when homosexual Christians are able to successfully integrate the two contravening identities into a single, new, workable understanding of the self, being a Christian homosexual. 


\section{METHODOLOGY}

A phenomenological qualitative research approach was chosen for the study in order to obtain insights into the experiences, views and opinions of homosexual and bisexual students about their Christian faith. This type of design was selected due its flexibility which would allow for defining the exploration of themes, enhancing understanding of new terms, as well as the clarification of existing concepts (Creswell 2009, 203). Inclusion criteria for participants included that participants had to be homosexual or bisexual, participants needed to consider themselves to be Christians, and lastly, they had to be a student at the University of the Witwatersrand (WITS). Snowball sampling was used to invite potential participants and individual interviews were conducted face-to-face. The researcher used a semi-structured interview schedule to obtain data and interviews were recorded with participants' consent. A pre-test was conducted to ensure the appropriateness of the schedule with two students who met the criteria for the study. As a result of the pre-test, subsequent changes were made to enhance the validity of the tool, and the pre-test interviews were not incorporated in the final analysis. The interview schedule incorporated questions to explore the following research objectives:

- To understand the views and opinions held by homosexual Christians with regards to the Bible's teachings on the topic of homosexuality

- To explore the views and opinions Christian homosexuals have about the church's response to their sexuality

- To understand how homosexual Christians integrate their sexual orientation with their Christian faith

- To elicit information on the level of interaction and integration homosexual Christians experience in the Church and with the Christian community at large.

Thematic content analysis was used to analyse the data. To enhance the trustworthiness of the study the research tool was pretested and the same researcher conducted all the interviews. Ethical clearance for this study was obtained from the Human Research Ethics Committee at the University of the Witwatersrand. Ethical principles of beneficence, informed consent, voluntary participation, autonomy, confidentiality and anonymity informed the study. In particular, privacy and confidentiality were crucial to this study as participants expressed very personal views on two very sensitive topics, sexuality and religion. Furthermore, participants' identities were protected, especially as they may have not come out about their sexual orientation to others. Participants were offered counselling from the Counselling and Career Development Unit at Wits University if they felt it was necessary after talking about these 
sensitive issues in the research interviews.

\section{Demographic profile of participants}

Ten students participated in the study, including two black females and eight black males. Participant's ages ranged from 18-26, with the average age of participants being 22. The participants were all Christians and belonged to different Christian denominations: three were Roman Catholic; five were Protestant; one was a Seventh Day Adventist and one did not belong to any specific denomination. Both female participants were lesbian, seven of the male participants were gay and one male participant was bisexual, meaning that he was sexually attracted to both males and females. There were no transgendered students in the sample. Participants were given pseudonyms to protect their identities. The pseudonyms were selected considering the ethnicity of the participant. In South Africa, it is common practice that people move to the bigger cities in pursuit of furthering their studies as there are many universities and colleges in the cities. As such only three participants were originally from the Gauteng Province, three from the Eastern Cape Province, two from KwaZulu-Natal, one from the Free State and one from the Limpopo province.

Participants were studying in various faculties which ranged from Law and Commerce (four participants); Humanities (four participants); Science (one participant) and Medicine (one participant) (See Figure 1). All the participants were students at the University of the Witwatersrand; most (seven) were undergraduates while three participants were completing post graduate degrees.

\section{FINDINGS AND DISCUSSION}

\section{Accepting the Christian faith}

Upon being asked to explain how participants had become acquainted with the religion of Christianity, all the participants explained that they were born into the faith. Through socialisation, Christian values and culture were assimilated. This theme is captured in the following responses:

You know when you come from a Christian background you get swallowed into the religion (Roto, male).

I can't remember not knowing Christianity. I was brought up in a family where every Sunday everyone went to Church (Thami, male). 


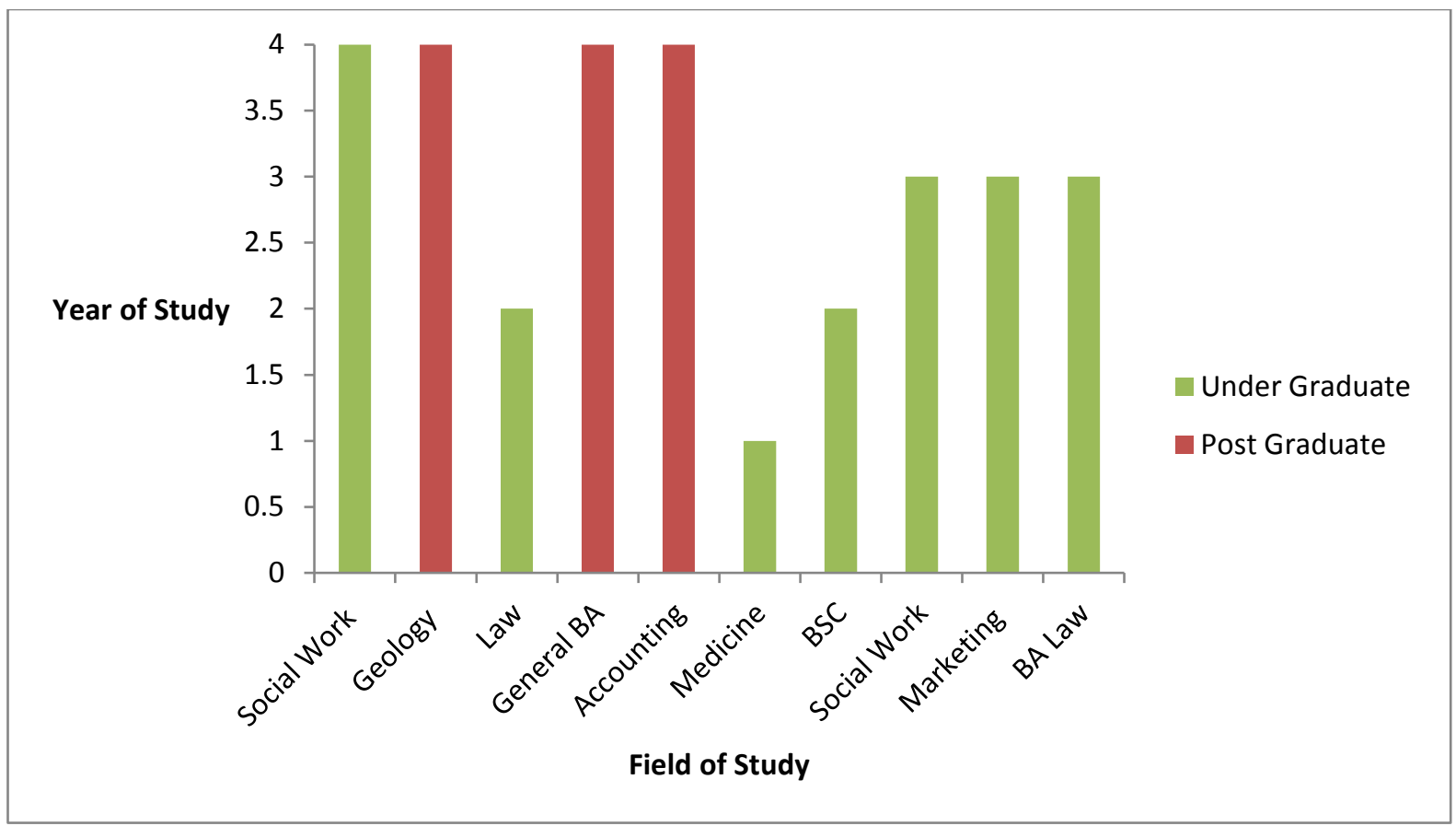

Figure 1: Participants' field of study and year of study $(\mathrm{N}=10)$

All the participants acknowledged how during their teenage years they had made the conscious decision to identify themselves as Christians and had also freely adopted the values of Christianity. Participants spoke about how they were socialised into the religion of Christianity through their parents, family, and the church. In the process of socialisation children or any other person learns and adopts norms. Norms refers to what is appropriate and what is inappropriate, the roles, and also what is expected by society of someone in their role and also their behaviour in general (Shepard 2009). Relating to social identity theory, participants acceptance of the Christian faith involved the processes of social categorisation and social identification. Participants were taught about the Christian faith (social categorisation) and assimilated many of the teachings, beliefs and practices of the Christian faith and incorporated them into their religious identity (social identification).

\section{Being a Christian and realising that you're attracted to people of the same sex}

Participants identified that they had felt sexual attraction towards the opposite sex at a very early age, some as young as four or five. However as they got older they realised that their sexual attractions did not comply with heterosexual expectations. Their feelings for the same sex only became problematic when they learnt the word to define these feelings as 'homosexual'. Only once their feelings had been given a name, did they see and experience these feelings in a totally different way. The following responses, encapsulates some of these experiences: 
I was very very young hey, but I didn't understand what exactly it was ... I became very concerned after I read in a book that I am actually gay, all these feelings meant that I am gay (Rotonda, male).

My feelings for girls were the most normal thing until my parents got called into the school for my asking a girl to be my valentine, that is when I realised that liking people of the same is not acceptable (Asanda, female).

I always knew that there was something different about me, and I liked it until I realised that I was different because I was gay (Mzwanele, male).

In line with these findings, constructivists advocate that sexuality is subject to different cultural variations and that sexual orientations are socially constructed. Existentialists believe that sexual orientations are grounded in biology and have limited cultural influences (Haslam and Levy 2006, 472-485). Within the Christian faith, the expectation is that when one has reached an acceptable age, one will marry a person of the opposite sex and start a family through means of procreation. However, this linear projection is not as straightforward for homosexual individuals. Their process of love and relationships deviates from the standard expectations of Christianity. Social learning theory suggests that learning and the formation of identity occurs as a response to social stimuli. Our behaviours and attitudes develop in response from reinforcement and encouragement from those around us (Anderson and Taylor 2007, 81). Accepting their sexuality was not necessarily easy, as social responses to their awakening sexuality made participants feel different and labelled. Furthermore, the Christian teaching of homosexuality 'being a sin' was often confusing for participants as they wrestled with their sexual identity.

Table 1: Participants' emotions experienced whilst coming to terms with being homosexual $(N=10)$

\begin{tabular}{|c|c|c|}
\hline Theme & $\begin{array}{l}\text { Number of } \\
\text { participants }\end{array}$ & Quotations to illustrate the theme \\
\hline Confusion & 3 & $\begin{array}{l}\text { 'I was so confused. I had never met a gay person in my life } \\
\text { besides myself' (Rotonda, male). } \\
\text { 'I didn't know what was happening because I clearly understood } \\
\text { that this is wrong' (Zandile, female). } \\
\text { 'I didn't even know who to ask or who to talk to because I knew it } \\
\text { was a sin, and I couldn't out myself to anyone' (Thami, male). }\end{array}$ \\
\hline Denial & 4 & $\begin{array}{l}\text { 'I began to over masculinise myself' (Nhlanhla, male). } \\
\text { 'I started off as bisexual actually; I couldn't accept that I'm } \\
\text { lesbian' (Asanda, female). } \\
\text { 'I had quite a few girlfriends at once, to prove that I'm not only } \\
\text { straight but I am a player also' (Sihle, male). } \\
\text { 'I started wearing dresses. I even forced myself to have a crush } \\
\text { on a guy' (Zandile, female). }\end{array}$ \\
\hline $\begin{array}{l}\text { Anger towards } \\
\text { God }\end{array}$ & 4 & $\begin{array}{l}\text { 'I always asked God why did this have to happen to me, why } \\
\text { didn't he give me a fair chance at life' (Vuyo, male). } \\
\text { 'My family and I are so devoted to you, why would you punish us } \\
\text { so badly' (John, male). } \\
\text { 'God said he loves me but why would he give me that is going to } \\
\text { make the whole world hate me' (Roto, male). } \\
\text { 'God is unfair' (Asanda, female). }\end{array}$ \\
\hline Bargaining with & 4 & 'I prayed with all my might, I fasted for days just praying that God \\
\hline
\end{tabular}




\begin{tabular}{|l|l|l|}
\hline Theme & $\begin{array}{l}\text { Number of } \\
\text { participants }\end{array}$ & Quotations to illustrate the theme \\
\hline God & & $\begin{array}{l}\text { takes it away' (Sihle, male). } \\
\text { 'I gave God time frames, I would ask him to prove that he loves } \\
\text { me by taking these feelings away'. } \\
\text { 'I even got baptised, thinking that my sin would be washed away' } \\
\text { (Zandile, male). } \\
\text { 'I pray hard and asked God to take it away, I even swore that I } \\
\text { would deliver the good news of salvation to everyone I met' } \\
\text { (Vuyo, male). }\end{array}$ \\
\hline $\begin{array}{l}\text { Shame and self- } \\
\text { loathing }\end{array}$ & \multirow{5}{*}{$\begin{array}{l}\text { 'I kept it a secret. It's still a secret to others even now' (Nhlanhla, } \\
\text { male) } \\
\text { 'I hated myself so much that I tried to kill myself so that I wouldn't } \\
\text { be this disgrace that I am' (Zandile, female). } \\
\text { 'I was so ashamed of myself; I went through a phase of } \\
\text { depression' (Sihle, male). } \\
\text { 'I didn't feel clean; I didn't even want to be around other people, } \\
\text { that's how much I disgusted myself' (Mzwanele, male). }\end{array}$} \\
\hline
\end{tabular}

Table 1 shows different emotions that participants felt during the process of coming to terms with their sexuality. For most of the participants this experience was also a spiritual journey as they looked to God to help them deal with their sexuality. Only one participant felt that he did not go through an emotional journey in accepting his sexuality. Acknowledging that he always felt different to others, his family's unconditional acceptance helped him to be at peace with who he was. What was apparent from the emotions that participants identified in Table 1 was that the second stage of social learning theory, the social identification stage was problematic for participants as their growing sexual identity was often in conflict with fundamentalist Christian perspectives and African cultural views. This inner turmoil and reflections upon social identification, resulted in participants starting to question their identification with their own ingroup and compare and potentially view other out-groups as more desirable than the particular Christian group with which they had initially identified.

\section{Participants' views about the Bible's teaching on homosexuality}

While the condemnation of homosexual acts in the Bible appears fairly unambiguous, this factor is only relevant if one views the Bible to be morally sound and that the biblical writers were not story tellers but actual channels for the voice of God (Hand 2007, 78). None of the participants felt that the Bible was an authentic authority of what is acceptable in the eyes of God. They justified this view as they felt that the Bible was written in a specific historical and cultural context and questioned whether the Bible should be interpreted literally. Slavery, polygamy, subordination of woman, animal sacrifice are all sanctioned in either the Old or the New Testament, practices which are not condoned by many societies today (Sumerau, Padavic and Schrock 2015, 306; Hand 2007, 77).

While participants mostly indicated that they found the Bible oppressive and unreliable, 
five of the participants expressed the comfort that they found in reading the text. As these participants explained, they would rather focus on the sections of the Bible which reaffirmed God's love and acceptance of them as homosexuals, than give credence to the six or seven scriptures that speak against homosexuality.

After all is said and done I always sit to myself and think that the Bible says that God created me in his own image. Why am I so worried then? (Mzwanele, male).

God would never make a faulty productive, after all I did not choose this, my father created me in His own image (Mbongeni, male).

It doesn't make sense that God would create us this way only to condemn us, Isaiah 1 verse 18 says the Lord accepts us as we are (John, male).

The Bible says God knew me even before I was born, he knows what is happening to me, and he knows that I have no power to change it (Asanda, female).

I know that my Father loves me. In the Bible it says Jesus died for all our sins. If being gay is a sin then my Jesus has died for it (Vuyo, male).

Focusing on the essence of Christianity, which, includes the deeper message of forgiveness and spiritual reconciliation, motivated participants to continue in their journey of Christian faith and getting to know God. Participants focused on the greater message in the Bible which is love and forgiveness. Because of the comfort that these participants found in the Bible they were motivated to continue in their journey of Christianity and getting to know God more.

In terms of social identity theory, participants may have questioned the legitimacy of the Christian group to which they belonged. As most churches do not see homosexuality as complementary to the Christian faith, these ideals would have challenged participants' sense of belonging and self-identity. As Niens, Cairns, Finchilescu, Foster and Tredoux (2003, 109) explain the perceived loss of legitimacy of the in-group results in a 'negative social identity' and evokes one of the three responses from an individual: Individual mobility; social creativity (change of comparison group or change in comparison dimension) and social competition. As Bosman $(2009,1)$ explains, many gay Christians may look beyond their own churches due to the churches discriminatory beliefs about homosexuality and find a new spiritual home (individual mobility). As new relationships are formed, a deeper sense of meaning and existence may also be experienced.

\section{'Coming out' to family members}

'Coming out' is the term used to describe the act of letting people know that you are not a heterosexual through means of dating people of the same sex freely and openly. In fact the issue of 'coming out' was seen to be a contentious one. Three participants felt that they did not owe any explanations to others about who they were and said: 
I find it unfair that we have to come out, I've never heard of anyone sitting anyone down to explain to them that they are straight (Nhlanhla, male).

... they have known me my whole life, and besides, I don’t owe anyone any explanations (Roto, male).

I'm not coming out to anyone until someone comes out to me announcing how much of a man or a woman they are (Mzwanele, male).

Hand $(2007,69)$ contends that homosexuality should not be viewed by society as a 'contentious issue' but instead should be viewed as morally legitimate or unproblematic. Only three of the participants had 'come out' and openly spoken about their sexual preferences to their families. Most participants did not want to be open with their family and cited numerous reasons for this stance, including the fact that their parents were homophobic; the fear that they would be disowned; their family would deny or avoid the issue; or the concern that their family would be disappointed. One participant explained that being a student, she was still financially dependent on her parents:

I'm still financially dependent on my parents, I feel I like I will be comfortable telling them when I know that even if they cut ties with me, I am not depending on them for anything (Asanda, female).

Participants who had come out to their families had mostly experienced the kinds of family reactions that were anticipated by those who had not come out. The responses revealed how some parents battled to accept their children's choices:

My mom hates it, my mom is too religious, she hates it she even prayed that God kills me for being gay (Thami, male).

My mom doesn't want to hear anything about it, its Satanism as far as she is concerned (Vuyo, male).

My mom always includes it in her prayers, even though she has never said it to me, she has made it quite clear that she thinks being gay is unnatural and we are possessed by some kind of demon (Zandile, female).

The perceived loss of family or an important social grouping can be very unsettling and for some even traumatic. Consequently, participants were reluctant to openly admit and acknowledge their identification with a social group that may have been considered an outgroup by many. As a result most of the participants had not 'come out'. Some participants felt that the timing was not yet appropriate to come out to their families but felt that they would be supported when they did share with family members. Only one participant felt that his family's unconditional acceptance of his sexuality helped him to be at peace with who he was. 


\section{The church and Christians' response to participants' sexuality}

Whilst churches in the city appeared to be less condemning of homosexuality than churches in the rural areas, there does not appear to uniformity amongst Christians about the issue of homosexuality. Sumerau, Padavic and Schrock $(2015,306)$ note the contradictions that exist between Christian denominations as some vilify homosexuality whilst others, for example, mainstream liberal Protestant denominations, have recently started recruiting LGBT members. Only the participants who attended a Roman Catholic Church felt that they were not discriminated against by the church on the grounds of their sexuality. For most participants the most common strategy was to keep their sexuality a secret from the church for fear of rejection. Instead participants observed how their fellow church members responded to issues pertaining to homosexuality and subsequently decided not to disclose their sexual identity. Participants were concerned about the judgmental attitudes of most Christians, and felt that these prejudicial attitudes did not resonate with the essence of the Christian message of forgiveness and love. These sentiments were evident in the following quotations:

I wonder if Christians are familiar with the commandment that says thou shall not judge. Christians are the most judgemental people on earth (Asanda, female).

I have been judged less by non-Christians (Thami, male).

Feelings of disappointment with fellow Christians were also apparent, as participants did not feel that they received the expected support and nurturance from their faith. Instead, criticism and judgement were conveyed, as reflected in the following quotations:

When people look at you in disgust, that you even ask yourself if you're still at church. I don't know if Christians don't realise that they all have their own sins, it's just that we don't know about them (John, male).

They never tried to understand me as a person, they just saw demons and starting bombarding me with Bible verses (Zandile, female).

It pains when people treat you like less of a person for something that you didn't even choose yourself, you'd think Christians would be more compassionate (Asanda, female).

Most Christian churches predominantly view homosexuality as a violation of God's law and a threat to family values (Kaoma 2014, 229). Participants were concerned with what they felt were levels of hypocrisy amongst Christians. They explained that that they were judged on a daily basis by their fellow Christians because their sin was external, yet the Christian faith advocates that everyone is a sinner. Drawing upon social identity theory, one of the central hypotheses of this theory is that in order to enhance one's own self-esteem and beliefs, members of an in-group will find negative aspects about an out-group, often resulting in prejudice and 
discriminatory behaviours towards the out-group (McLeod 2008, 4). In this regard Haslam and Levy $(2006,484)$ raise the question whether fundamentalist beliefs serve as a form of 'boundary reinforcement' and is an ego-defensive response that helps fundamentalists to feel validated, in this way being assured that their approach to sexuality is the correct one.

\section{CONCLUSIONS AND RECOMMENDATIONS}

Participants did not view their sexuality as 'abnormal' and 'sinful' and therefore did not feel a need to reconcile the two concepts of homosexuality and Christianity. They perceived their relationship with Christ as the same as that of any other Christian. Participants were mostly impacted or affected in the beginning stages of realising and accepting that they were sexually attracted to people of the same sex. This realisation affected them negatively as they became aware that who they were was contradicting what was stated in the Bible about being desirable or acceptable in the eyes of the Lord. Most of the participants reported feelings of confusion, anger, denial and self-loathing in the initial stages of their realisation. However, as time progressed they moved into the stage of accepting that there was nothing that they could do to change. This acceptance emerged after many days of fasting, prayer, and negotiating with God to take away their feelings of same sex attractions.

All participants had often experienced discrimination and prejudice from the church. They felt that it was unfair that they were persecuted for a sin that they did not choose to commit and over which they had no control. The participants reported experiencing hostility almost on a daily basis and consequently, they had adapted coping strategies which they felt make them appear rude and harsh to others. Through acknowledging the need to first be true to themselves, participants realised that their sexuality was a matter between God and themselves.

The issue of homosexuality and Christianity is perhaps more complicated than initially perceived by many. Accepting their homosexuality was an emotional journey for the participants, especially since the predominant message from the church is that these two concepts cannot coexist. Participants spoke of the inner turmoil that they had undergone whilst working through and accepting their sexual orientation. For participants this process was also a spiritual journey as they sought solace and guidance from God. Initially this meant fasting and praying for their sexual desires to change in order to conform to society's expectations of a Christian. Hostile responses of Christians to gay issues often caused the participants to cease fellowship, which further isolated participants. However, this isolation yielded different results as some felt that they were stronger in their spiritual beliefs and not having to rely on others to dictate the terms of their spirituality, religious and cultural identity. Social identity theory 
explains this process as subordinate and superordinate recategorisation as participants reviewed the social categories to which they had initially identified and then expanded or narrowed their initial understandings of these social categories (Niens et al. 2003, 110). The result of this process was that participants could merge their sexual identity and their religious beliefs into one, despite differing cultural and religious views on the matter. For others ceasing fellowship had adverse effects upon their relationship with God as they felt a void was created which moved them further from God. Recommendations for further research would include:

- $\quad$ Research should be conducted to explore the effects on academic performance of students who are struggling to accept and integrate their sexual orientation and their religion;

- The opinions of campus pastors or ministers on the complementary or contradictory understanding of homosexuality and Christianity need to be explored;

- A similar study should be conducted with a larger sample at another university. In particular women should be included in the study so that the views of women students on this subject are explored;

- It would be interesting to conduct a similar study at a university that is located in a rural area and then compare the findings from this study which was undertaken at a university located in an urban area in order to test the assertion in this research that it appears the urban areas are more accommodating of the LGBT community than the rural areas.

The challenge is for all sectors of society, including religious and academic institutions to examine the manner in which they address marginalised groups. Not only should there be support provided for individuals who wrestle with aspects of their sexual orientation but proactive campaigns need to be conducted promoting and celebrating difference. University student counselling centres have a vital role to fulfil in this regard. Essentially it is the individual's decision as to whether he/she believes that Christianity and homosexuality can coexist. At the end of the day we each have to live with our own choices.

\section{ACKNOWLDEGEMENT}

This work is based on the research supported in part by the National Research Foundation of South Africa (Unique Grant No 92681).

\section{REFERENCES}

Anderson, M. and H. Taylor. 2007. Sociology: Understanding a diverse society. $4^{\text {th }}$ Edition. Wadsworth, United States of America: Thompson. 
Bosman, J. 2009. Re-interpreting the spiritual experience of gay men in the Pentecostal/Charismatic tradition. Practical Theology in South Africa 23(1): 1-18.

Boswell, J. 1979. The church and the homosexual: An historical perspective, 1979. http://sourcebooks. fordham.edu/pwh/1979boswell.asp (accessed 15 June 2015).

Creswell, J. W. 2009. Research design: Qualitative, quantitative and mixed methods approaches. $3^{\text {rd }}$ Edition. London, United Kingdom: Sage Publishers.

Crooks, R. and K. Baur. 2013. Our sexuality. $12^{\text {th }}$ Edition. Colorado, United States of America: Benjamin/ Cumming Publishers.

Driscoll, M. and G. Driscoll. 2012. Real marriage: The truth about sex, friendship, and life together. Tennessee, United States of America: Thomas Nelson Inc.

Ellens, J. 2006. Sex in the Bible: A new consideration. Westport, United States of America: Praeger Publishers.

Epprecht, M. 2013: Sexuality and social justice in Africa: Rethinking homophobia and forging resistance. London: Zed Books.

Gerhards, J. 2010. Non-discrimination towards homosexuality: The European Union's policy and citizens: Attitudes towards homosexuality in 27 European Countries. International Sociology 25(1): 5-28.

Gnuse, R. K. 2015. Seven gay texts: Biblical passages used to condemn homosexuality. Biblical Theology Bulletin 45(2): 68-87.

Hand, M. 2007. Should we teach homosexuality as a controversial issue? Theory and Research in Education 5(1): 69-86.

Haslam, N. and S. R. Levy. 2006. Essential beliefs about homosexuality: Structure and implications for prejudice. Personality and Social Psychology Bulletin 34(2): 472-485.

Henry, M. 1811. Matthew Henry's commentary on the Whole Bible: Complete and unabridged. http://www.biblestudytools.com/commentaries/matthew-henry-complete/ (accessed 22 June 2015).

Kaoma, K. 2014. The paradox and tension of moral claims: Evangelical Christianity, the politicization and globalization of sexual politics in sub-Saharan Africa. Critical Research on Religion 2(3): 227-245.

Kutsch, T. 2013. Homosexuality still a crime in 38 African countries. http://america.aljazeera.com/ articles/2013/11/14/senegala-s-criminalizationofhomosexualitypartofaregionaltrend.html (accessed 2 February 2016).

Lopang, W. 2014. No place for gays: Colonialism and the African homosexual in African literature. International Journal of Humanities and Social Science 4(9): 77-83.

Masango, M. 2002. Homosexuality: A challenge to African churches. HTS: Theological Studies 58(3): 956-972.

McLeod, S. A. 2008. Social identity theory. www.simplypsychology.org/social-identity-theory.html (accessed 3 November 2016)

McNeil, J. J. 1993. The church and the homosexual. Boston, United States of America: Beacon Press.

Mirke-Sellassie, G. A. 2000. Early translation of the Bible into Ethiopic/Geez. The Bible Translator 51(3): 302-316.

New Zimbabwe. 2014. Mugabe threatens to expel gay promoting diplomats. Staff reporter, 18 April 2014. http://www.newzimbabwe.com/news5320Mugabe+to+expel+gay+promoting+envoys/ news.aspx (accessed 5 May 2015).

Niens, U., E. Cairns, G. Finchilescu, D. Foster and C. Tredoux. 2003. Social identity theory and the authoritarian personality theory in South Africa. South African Journal of Psychology 33(20): 109-117.

Newman, B. M and P. R. Newman. 1999. Development through life: A psychosocial approach. Belmont, 


\section{CA. Brooks/Cole Wadsworth.}

Phillips, R. 2005. Conservative Christian identity and same-sex orientation: The case of gay Mormons. New York, NY: Peter Lang Publishing Inc.

Rodriguez, E. M. and C. S. Ouellette. 2000. Gay and lesbian Christians: Homosexual and religious identity integration in the members and participants of a gay-positive church. Journal for the Scientific Study of Religion 39(3): 333-347.

Rosario, M., E. Schrimshaw and J. Hunter. 2011. Different patterns of sexual identity development over time: Implications for the psychological adjustment of lesbian, gay, and bisexual youths. Journal of Sex Research 48(1): 3-15.

Sakin Ozen, N., I. Ercan, E. Irgil and D. Sigirli. 2010. Anxiety prevalence and affecting factors among university students. Asian-Pacific Journal of Public Health 22(1): 127-133.

Schuck, K. D. and B. J. Liddle. 2001. Religious conflicts experienced by lesbian, gay, and bisexual individuals. Journal of Gay \& Lesbian Psychotherapy 5(2): 63-82.

Shepard, J. M. 2009. Cenage advantage books: Sociology. $10^{\text {th }}$ Edition. Wadsworth, United States of America: Cenage Learning.

Subhi, N., D. Geelan, M. McMahon, K. Jusoff, S. M. Mohamad, N. Sarnon, S. Nen, S. Hoesni, S. T. Chong, I. Fauziah and K. Alavi. 2011. A better understanding of the potential conflict between Christianity and homosexuality. World Applied Sciences Journal 12(SPL ISS): 13-19.

Sumerau, J. E., I. Padavic and D. P. Schrock. 2015. Little girls unwilling to do what's best for them: Resurrecting patriarchy in an LGBT Christian church. Journal of Contemporary Ethnography 44(3): 306-334.

Tajfel, H. and J. C. Turmer. 1979. An integrative theory of intergroup conflict. In The social psychology of intergroup relations? ed. W. G. Austin and S. Worchel, 33-47. Monterey, California: Brooks/Cole.

University of the Witwatersrand. 2014. Safe zones. http://www.wits.ac.za/safezones (accessed 22 June 2015).

Waidzunas, T. 2015. Reviews: Pray the gay away. American Sociological Association 44(2): 171-172.

Yarhouse, M. A. 2010. Homosexuality and the Christian: A guide for parents, pastors, and friends. Minnesota, United States of America: Baker Publishing Group. 